\title{
ECOHYDROLOGICAL INVESTIGATION OF PLAIN RIVER SECTION IN THE AREA OF SMALL HYDROELECTRIC POWER STATION INFLUENCE
}

\author{
Korzhov Ye. I.
}

\section{INTRODUCTION}

The mode of operation of a hydroelectric power station is one of the main abiotic factors regulating the status of aquatic ecosystems of the river on which it is installed. The ecologically unjustified regime of the hydropower station can lead to significant ecological consequences and irreversible changes in the processes of formation of water quality, biodiversity and building stable trophic connections in the area of direct influence.

The more electricity is produced, the greater the environmental impact of the station. Equally important is the level of inter-annual regulatory capacity of hydroelectric power stations. The small hydroelectric power stations (with installed capacity not exceeding 5 $\mathrm{MW}$ ), which have no regulating capacity, have the smallest impact on the aquatic ecosystem. In this paper, we will consider the ecohydrological aspects of the impact of the operation of small hydropower stations without intra-annual regulation on aquatic ecosystems and biotopes that are located in their area of influence.

The object of the study we have selected was the Myhiya hydroelectric power station, which is located on the left bank of the Southern Bug River near the village of Myhiya in the Pervomaisky district of the Mykolaiv region in Ukraine (Fig. 1).

The complex of hydroelectric power station includes a building with hydroelectric turbines, with a total area of $847.9 \mathrm{~m}^{2}$, a drainage channel of $124 \mathrm{~m}$ length, a spillway of overflow type of $208 \mathrm{~m}$ in length and a height of $2.25 \mathrm{~m}$. The normal propped level is $5.5 \mathrm{~m}$. The power installed on the HEPS tires is $750 \mathrm{~kW}$. 


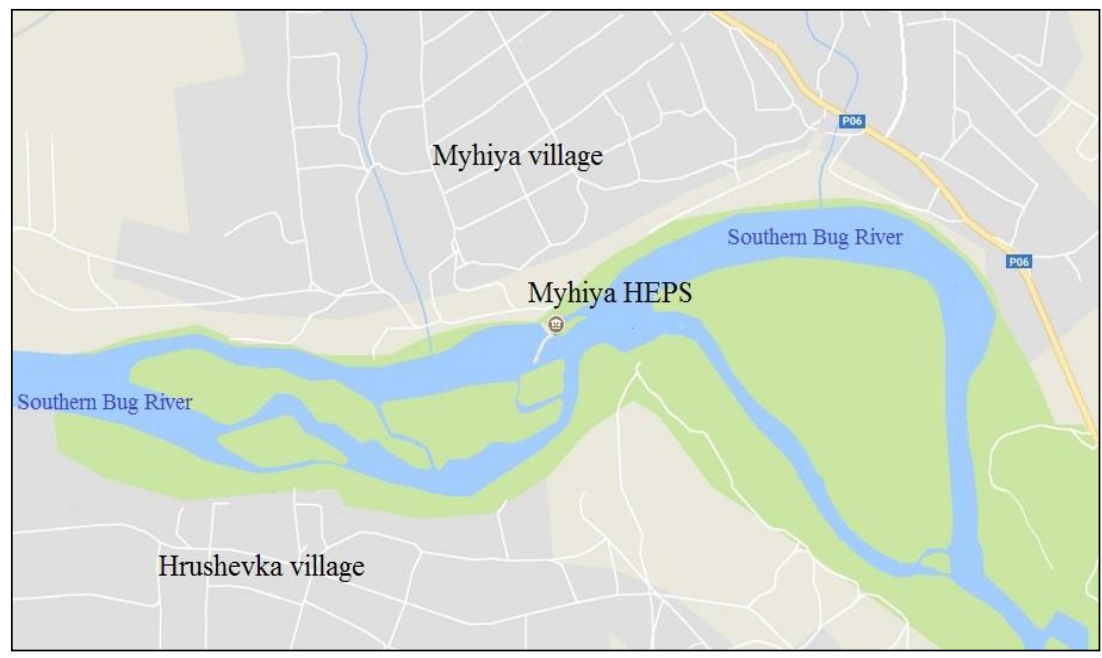

Fig. 1. Scheme of the Myhiya hydroelectric power station location

The largest settlements in the study area are the town of Pervomaysk (5 km upstream) and the Myhiya and Hrushevka villages, located near the hydroelectric power station along the left and right shores of the left sleeve of the Southern Bug River in the Pervomaisk region respectively.

The terrain has a slight slope in the southeast direction, which is 0.00034 . The terrain is shaped like a steppe plain, characterized by alternation of valleys with ravines and beams. The vegetation of the basin has the character of forest-steppe. The slopes of the shores in this area are mostly flat, overgrown with reeds and shrubs. In the course of the river, bumps and sills are often found, forming a heterogeneity in the distribution of depths, flow velocities, water transparency, sediments and other environmentally significant characteristics of the aquatic ecosystem.

We conducted research in July 2017 (before the launch of the Migia HEPS) and in July 2018 (after a year of the hydroelectric power station operation). The choice of such time periods made it possible to assess the effect of the operation of the hydroelectric power station on the aquatic environment state in the area of its operation, to identify elements of the redistribution of individual hydrological parameters after the commissioning of the hydroelectric power. 
For research, we used the methodological base of ecohydrology. Ecohydrology as an independent scientific field is recognized relatively recently. Since the 1970s-1980s, studies in Ukraine, Poland, and Russia have been widely developed with the aim of assessing hydrological processes for shaping the state of ecosystems of water bodies and watercourses, their bioproductivity, and water quality. As a result, three main blocks of hydrological factors that are most environmentally significant were identified. These are water balance and water exchange processes, intra-water dynamics, and hydrophysical properties of water masses and bottom sediments. Using this approach to the analysis of hydrological factors allows you to maximize their environmental significance and identify the most important aspects of the aquatic environment, by regulating which it is possible to rationally control the state of the water bodies ${ }^{1,2}$.

A few more outdoor visits have been established, with a flood zone territory, a view of the depression of the left sleeve of the Southern Bug River before rowing of the hydraulic branch $(350 \mathrm{~m}$ above the main power supply) until the main channel is lower than 130 $\mathrm{m}$. Itself in the assigned area is included in the introduction of the Myhiya HEPS.

Behind the hydrological indicators and morphological features, the zone is more likely to be divided into a number of woodlands, which, however, are almost different between themselves (Fig. 2).

The characteristic pattern of the access to the area is that there are a variety of abnormal factors in the middle ground, equally large for the flat aquatorium, there are significantly more floristic and unique complexes.

1 Тімченко В.М. Екогідрологія. Досвід досліджень у ДніпровськоБузькій гирловій області // Таврійський науковий вісник "Сучасні проблеми аквакультури”. 2003. Вип. 29. С. 187-192.

2 Тимченко В.М. Экологическая гидрология: предмет, задачи, методы, опыт исследований в Украине. Гидробиологический журнал. 1993. Вып. 29, № 4. С. 3-15. 


\section{Hydrographic characteristics and orography of the bottom}

Investigations were carried out on the section of the Southern Bug River, $350 \mathrm{~m}$ above and $150 \mathrm{~m}$ below the structure of the Myhiya hydroelectric power station. Depth distribution in the studied area is rather uneven (Fig. 3).

Data on the distribution of depths along the water area are given for a limited period under conditions of low water levels in the river (Nature survey from 18.07.2017). In other hydrological periods of the year the depths in the studied area are higher. The maximum depths are noted during the period of spring waterhole and are greater than those indicated by $0.5-0.7 \mathrm{~m}$.

The zone of maximum depths is located mainly in the central part of the study area and just before the hydroelectric dam. Depths here in the period of boundaries are 2.0-2.6 $\mathrm{m}$. The rest of the dam above is shallow. Along the left bank, the depths are $0.5-0.8 \mathrm{~m}$, at the bottom a considerable layer of sludge with vegetable detritus. In the area of the dam and between the rocky islands, there is also a shallow zone with a range of values of $0.5-0.9 \mathrm{~m}$. In this part, due to the high flow velocities, the bottom is represented by stones, pebbles on which various rheophilic species of higher aquatic vegetation grow.

In the lower side of the hydroelectric power station, the average depth is about $1.0 \mathrm{~m}$. The greatest depth is noted near the oval tunnel, and, at a distance of $5 \mathrm{~m}$ from it, on the day of observations was $2.5 \mathrm{~m}$. Further along the channel, the depth rapidly decreases to $0.6-1.0 \mathrm{~m}$. Due to the lack of water flow, the bottom is muddy, overgrown with water vegetation and clogged with tree fragments. At the point of exit of the water from the outlet channel at a distance of $55 \mathrm{~m}$ from the dam, the soil changes to muddy sand with shell detritus, well washed.

\section{Water flow, its variability and intra-annual distribution}

Myhiya HEPS is located $609 \mathrm{~km}$ from the source. The catchment area of the Southern Bug River near Myhiya village is $44230 \mathrm{~km}^{2}$, the average long-term value of water consumption in terms of this area is $81.9 \mathrm{~m}^{3} / \mathrm{s}$ or 2583 million $\mathrm{m}^{3}$ per year. 


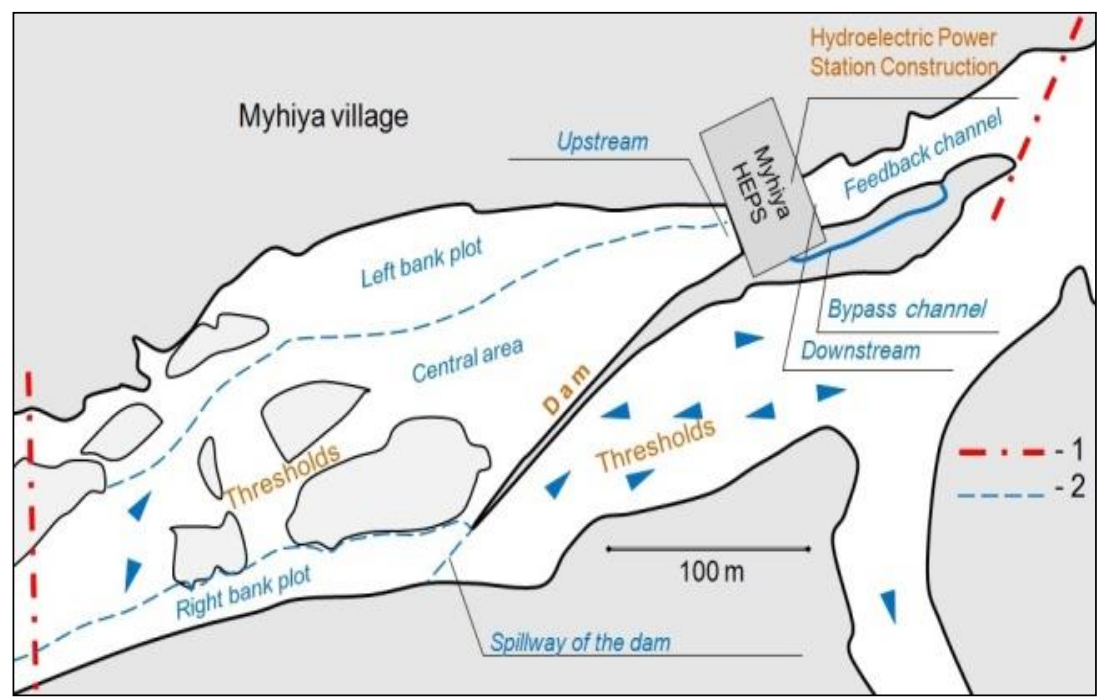

Fig. 2. The boundaries of the Myhiya hydroelectric power station influence zone (1) and the location of the water areas hydrological-morphological features (2)

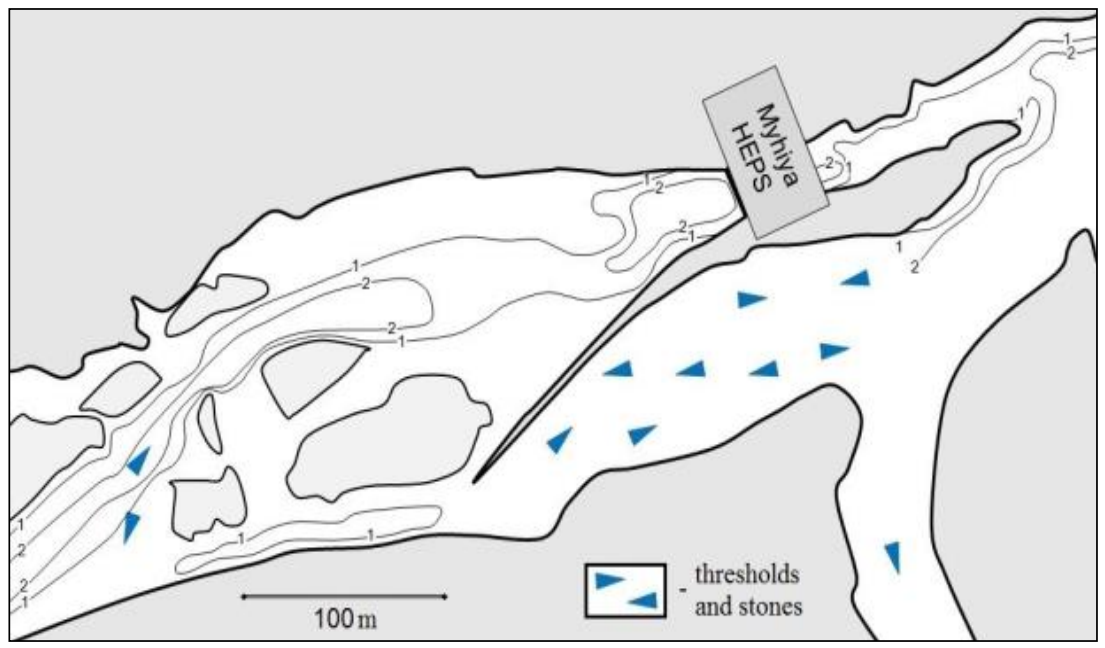

Fig. 3. Scheme of the area of e Myhiya HEPS influence in isobates (m) in the low hydrological season. According to the materials of full-scale shooting 18.07.2017 
Data were recovered for the study area by the method of interpolation with neighboring posts, taking into account local factors. The analogue data is selected from the water post of the Alexandrovka village for a long period (1914-2012) ${ }^{3}$. The difference between the catchment areas of the river between these points is almost $2000 \mathrm{~km}^{2}$, which is $4.5 \%$ as a percentage.

According to the average annual water consumption, we have constructed a supply curve for the Southern Bug River in the region of Myhiya village (Fig. 4).

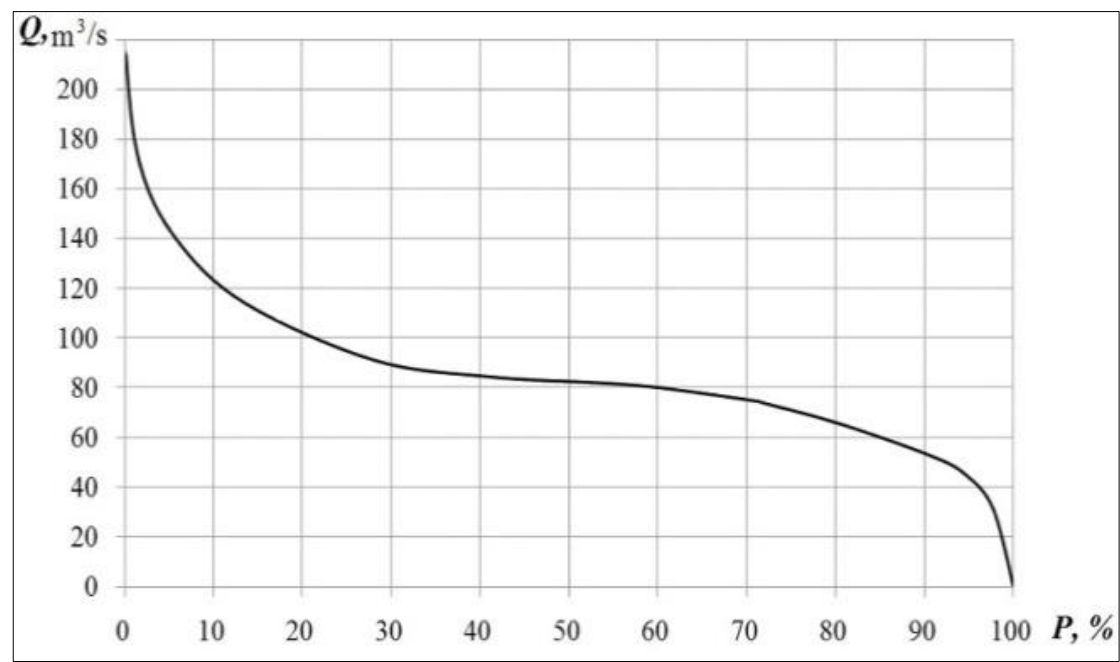

Fig. 4. Current water supply curve in the area of Myhiya village in the modern period. $Q_{m}=81,9 \mathrm{~m}^{3} / \mathrm{s}, C_{V}=0,39, C_{S}=2 C_{V}$

The variation coefficient of water flow in the area of hydroelectric power station $\left(C_{V}\right)$ is 0.39 , which indicates a moderate variability of river flow over many years. Based on the calculated values of $Q_{m}$ and the coefficients of $C_{V}$ and $C_{S}$, we obtained the values of average annual water flow in low-water, average water and high-water years under current conditions (Table 1).

3 Водне господарство в Україні. За ред. А. В. Яцика, В. М. Хорєва. 2000. $456 \mathrm{c}$. 
Estimated water flow of the Southern Bug River in the Myhiya village in the characteristic water years

\begin{tabular}{|c|c|c|c|c|}
\hline $\begin{array}{c}\text { Characteristic of the } \\
\text { year }\end{array}$ & $\begin{array}{c}\text { Probability } \\
P, \%\end{array}$ & $K$ & $\begin{array}{c}Q, \\
\mathrm{~m}^{3} / \mathrm{s}\end{array}$ & $\begin{array}{c}W, \\
\text { million } \\
\mathrm{m}^{3}\end{array}$ \\
\hline Low-water & 95 & 0,529 & 43,3 & 13655 \\
\hline Moderate low water & 75 & 0.874 & 71,6 & 22579 \\
\hline Medium & 50 & 1.000 & 81,9 & 25827 \\
\hline Moderate high water & 25 & 1.164 & 95,3 & 30053 \\
\hline High-water & 5 & 1,770 & 145,0 & 45727 \\
\hline
\end{tabular}

From the archival materials and passport data of the Myhiya HEPS, it is known that the maximum flow rate recorded in the hydroelectric turbines was $5320 \mathrm{~m}^{3} / \mathrm{s}$ (spring 1932), the minimum $3.3 \mathrm{~m}^{3} / \mathrm{s}$ (August 1936). A similar change in water content is also characteristic of the Southern Bug River.

The intra-annual flow distribution is typical of most plain rivers in Ukraine. It stands out for spring flood, summer and autumn fringes with autumn rains and winter. The spring flood, which runs from March to May, accounts for about 59\% of the annual water volume. The lowest water levels are from July to September. The share of flow during this period ranges from 2.2 to $5.5 \%$. In November, a short-term increase in river water content $(6.7 \%$ share $)$ is possible due to the flow of flood waters formed from precipitation. The share of water consumption in the winter months is about $12 \%$ of the total for the year.

\section{Dynamics of water masses}

The dynamic characteristics of the water masses in the study area are quite variable - at short distances the rapid flow can change to a station with almost no water flow. Such heterogeneous distribution of flow velocities in the area of the Myhiya hydroelectric power station influence is caused by morphological features of the channel network and distribution of flow over the water system. The exit of rocky rapids from the water, the presence of separate islands of different size and configuration, large rocks are accordingly reflected in the speed and 
direction of the flow of water and the formation of rolling and deep-sea sections.

Based on the materials of field observations of water consumption for the investigated area, we constructed a scheme for the distribution of time in the Myhiya village in the low-water period (Fig. 5)

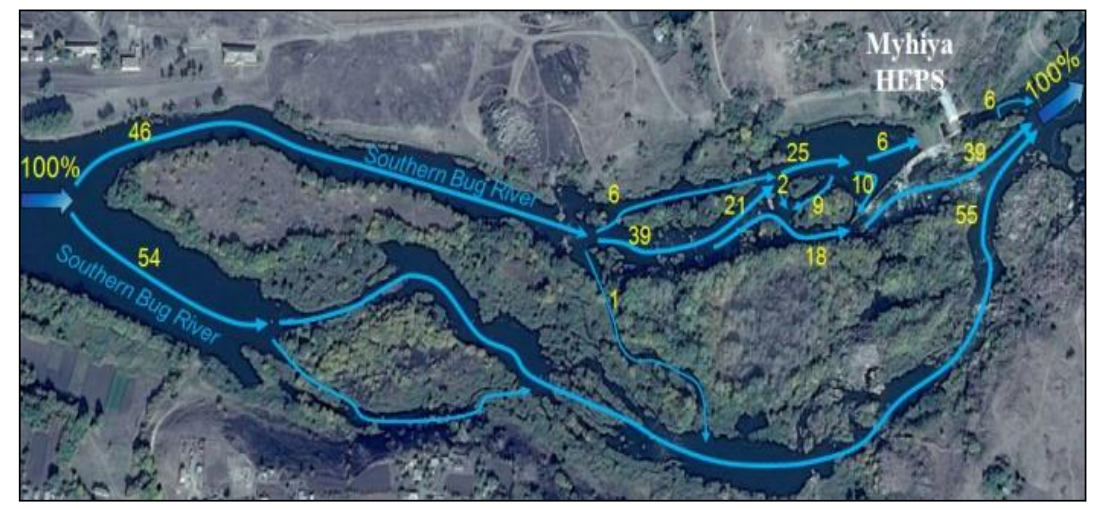

Fig. 5. Distribution of flow over the Southern Bug River water system in the region of Myhiya village in the low water period of the year. Figures on the diagram - the share of flow on a separate site in \% of the total river flow (water consumption $43 \mathrm{~m}^{3} / \mathrm{s}$ ). According to the materials of full-scale shooting 18.07.2017

From the above materials it can be seen that under the current conditions (with the turbines not working), only $16 \%$ of flow from the total volume from which only a part is transported to the outlet channel reaches the hydroelectric station. The other $10 \%$ is lost as a result of the transfusion of the water through the dam (mainly in its outermost part) and other channels. Such a cost distribution in the upper stream, especially near the left bank, creates favorable conditions for the siltation and sedimentation of small fractions.

The same situation occurs in the lower side of the hydroelectric power station, where good running water becomes only at the exit point of the discharge channel. Under modern conditions, in the downstream $60 \mathrm{~m}$ from the dam formed a stagnant shallow zone, which is significantly muddy (maximum silt capacity of $0.8 \mathrm{~m}$ ) and is almost completely overgrown with higher aquatic vegetation. 
Further downstream in the downstream, the silt zone extends along the left shore with a width of $15-25 \mathrm{~m}$ from the water cut. Such distribution of silt deposits indicates the presence of stagnant zones in the area of influence of hydroelectric power stations. In order to identify their location, we, based on field data, constructed a scheme of water circulation in the studied area. To do this, we used a twodimensional, horizontal plane mathematical model of water circulation, a full-flow method adapted for shallow depths ${ }^{4}$. As input parameters for the calculations, we used the morphometric indicators of the water object, the average values of inflow and outflow of water, meteorological data.

Circulation patterns clearly illustrate how water flow is distributed along the water area and the main (summary) direction of displacement of water masses at a particular site of a water body (Fig. 6).

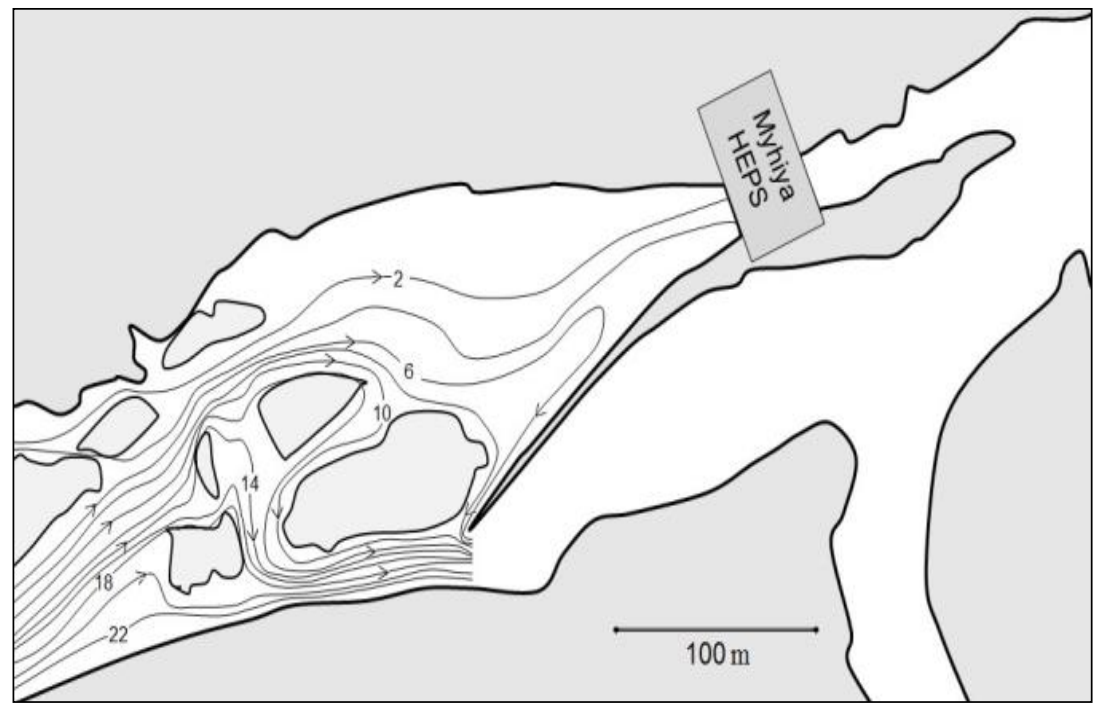

Fig. 6. Water circulation schemes in the area of influence of Myhiya HEPS under calm weather conditions (with turbines off). Current lines are given in $\mathrm{m}^{3} / \mathrm{s}$

4 Фельзенбаум А.И. Теоретические основы и методы расчета установившихся морских течений. 1960. 126 с. 
The results of mathematical modeling show that the most dynamically active section is the right-bank part of the object near the threshold exit and the far section along the dam. Under modern conditions (intermittent period, hydroelectric power turbines are switched off), water flows from the western part of the channel and flows mainly along the channels along the right bank. In the central part of the body of water, a large-sized stagnant zone is formed, which is located along the left bank and partly in the central part and extends to the dam of the hydroelectric power station. The velocity of flow in this zone, on the basis of full-time shooting materials, on 18.07.2017 averaged $0.03-0.08 \mathrm{~m} / \mathrm{s}$, in the central area it increased to $0.10-0.20 \mathrm{~m} / \mathrm{s}$, while in the area of the outlet of the stream through the dam at the thresholds of the flow increased to $1.20-1.40 \mathrm{~m} / \mathrm{s}$. Such heterogeneous distribution of flow velocities over a relatively short distance causes the formation of different types of biotopes coexisting in a small area. Along the left bank, mainly water flows, which are then diverted to the hydroelectric turbines, and the volume of this water depends on the capacity of the hydroelectric power station. Therefore, in order to increase the flow in the congested areas, an effective measure may be to pass more water through sewage and bypass channels, which will cause additional water supply to the leftbank and central sections of the water area and significantly improve their ecological status.

\section{Hydrophysical properties of water masses and sediments}

A less significant but no less important element of the hydrological regime for the object of study is the hydrophysical properties of the water masses, since they depend almost entirely on the intensity of the flow dynamics. The distribution of flow and the inhomogeneity of the flow velocity field in the area of the hydroelectric power station cause the formation of sites with different types of water masses and sediments. The study area is mostly shallow and porous, so despite the considerable content of substances suspended in water, the transparency of water masses in most cases reaches the bottom, the water temperature does not change with depth (Table 2). 
Table 2

Distribution of the main characteristics of water masses properties in different parts of the area of Myhiya HEPS influence

\begin{tabular}{|l|c|c|c|}
\hline \multicolumn{1}{|c|}{$\begin{array}{c}\text { The name of the site } \\
\text { according to Fig. } 2\end{array}$} & $\begin{array}{c}\text { Flow } \\
\text { velocity, } \\
\mathrm{m} / \mathrm{s}\end{array}$ & $\begin{array}{c}\text { Water } \\
\text { temperature, } \\
{ }^{\circ} \mathrm{C}\end{array}$ & $\begin{array}{c}\text { Water } \\
\text { transparency, } \\
\mathrm{m}\end{array}$ \\
\hline $\begin{array}{l}\text { Left bank above the } \\
\text { hydroelectric power station }\end{array}$ & 0,050 & 24,0 & $\begin{array}{c}0,7 \\
\text { (to the bottom) }\end{array}$ \\
\hline $\begin{array}{l}\text { The central section above the } \\
\text { hydroelectric power station }\end{array}$ & 0,200 & 23,5 & 1,6 \\
\hline $\begin{array}{l}\text { The shore along the dam } \\
\text { above the hydroelectric } \\
\text { power station }\end{array}$ & 0,700 & 23,0 & $\begin{array}{c}0,7 \\
\text { (to the bottom) }\end{array}$ \\
\hline $\begin{array}{l}\text { Upper hydroelectric power } \\
\text { station }\end{array}$ & 0,150 & 23,8 & $\begin{array}{c}1,6 \\
\text { (to the bottom) }\end{array}$ \\
\hline $\begin{array}{l}\text { Wastewater canal, the lower } \\
\text { side of the hydroelectric } \\
\text { station }\end{array}$ & 0,030 & 25,2 & 0,5 \\
\hline $\begin{array}{l}\text { Wastewater canal, } 60 \mathrm{~m} \\
\text { below hydroelectric power } \\
\text { station }\end{array}$ & 0,150 & 24,0 & $\begin{array}{c}0,5 \\
\text { (to the bottom) }\end{array}$ \\
\hline $\begin{array}{l}\text { Southern Bug River } 250 \mathrm{~m} \\
\text { below Myhiya hydroelectric } \\
\text { station }\end{array}$ & 0,118 & 24,0 & 1,8 \\
\hline
\end{tabular}

Only in the most stagnant areas (left bank above the hydroelectric power station, downstream at a distance of up to $50 \mathrm{~m}$ from the hydroelectric power station), as the water content of organic compounds increases, the water becomes less transparent, weak thermal stratification occurs, the water temperature in them is higher, than in more flowing sections of the water area.

The distribution of sediments is in good agreement with the position of stagnant and flowing sections of the water circulation scheme (Fig. 7).

Due to the almost complete absence of currents in certain areas of the water area, substances suspended in water are not able to remain in a state of sediment and sediment, which leads to their accumulation in the sediments. 


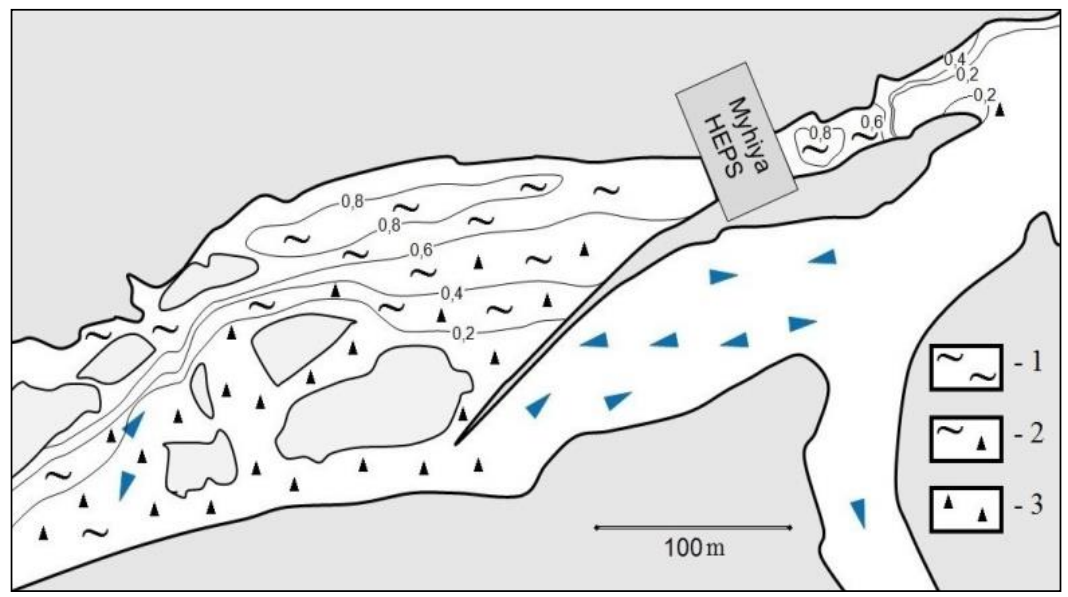

Fig. 7. Scheme of distribution of bottom sediments in the area of Myhiya HEPS. The figures show the sludge capacity in meters. 1 - organically saturated silt, 2 - silt on stones, 3 - pebbles, stones

Above the hydroelectric power station, the highest silt capacity is recorded along the left bank. The maximum capacity of the sludge layer here is $0.8 \mathrm{~m}$. The average particle diameter of the solid sludge fraction in the impact zone is $0.05 \mathrm{~mm}$. Then it gradually decreases in the direction of the right-bank part of the study area, where the bottom sediments consist mainly of pebbles and stones.

In the central part there is a transition zone where the soils are represented by silt on the rocks. The hilly and rocky bottom is the starting point for the river bed in the area. The distribution of sediments indicates that the mulching processes in these zones began here after the dam was closed, which altered the natural uniform distribution of costs along the waters and divided the study area into well-flowing and stagnant zones. In the discharge channel below the hydropower turbines at a distance of $60 \mathrm{~m}$ from the dam is also occupied by silt, whose power is unevenly distributed and averages 0.6 $\mathrm{m}$ (see Fig. 7). As above the hydroelectric power station, so in the feedback channel, sediments are predominantly $(60 \%)$ composed of organic matter. The channel bed in some places is clogged with tree branches and station detritus. The canal is approached by the bypass channel, which serves for removal of debris from the water intake of 
the hydroelectric power station, which in modern conditions transports some of the fresh water to the downstream. In the area around the outlet of the bypass channel, the soils are represented by sandbars and rifts of muddy sand.

The smallest fractions are noted in the lower basin of the Myhiya HEPS, as this site is the least flowing and the soils here are formed mainly from the sedimentation products of organic substances produced by the aquatic ecosystem.

\section{Assessment of the impact of the Myhiya hydroelectric power station restoration on the state of the aquatic environment}

The restoration of the operation of the Myhiya hydroelectric power station in environmentally hazardous changes in the studied area did not cause.

The commissioning of the hydroelectric power station did not cause changes in the annual flow volume, since it is of the dam type and has no regulatory ability either on a daily or seasonal scale.

After the hydroelectric power station was restored, there was some redistribution of flow over the water system of the investigated section of the Southern Bug River (Fig. 8). In the area above the dam, water consumption increased in the area of the left bank and in the central part of the water area.

Due to the operation of the hydroelectric turbines, the flow to the downstream has more than tripled and now accounts for $20 \%$ of the river's flow. The increase in the water content of this section was due to the decrease in the flow rate of water that had previously passed the thresholds. If, according to the data taken on July 18, 2018, 51\% of the water from the total flow of the Southern Bug River flowed through the thresholds, then after the start of the hydroelectric power station the water consumption here decreased by $15 \%$.

This redistribution of water consumption had a positive effect on the abiotic and biotic parameters of the area of the Myhiya HEPS influence. Flow rate increase of the left bank and the central section above the dam contributes to a greater dilution of the water collected here in the congestion zones. Due to the practical disappearance of the stagnant zones in these areas, the water masses became more transparent, the capacity of silt deposits decreased by $0.15-0.20 \mathrm{~m}$, the color of water changed from yellow to yellow-green. 


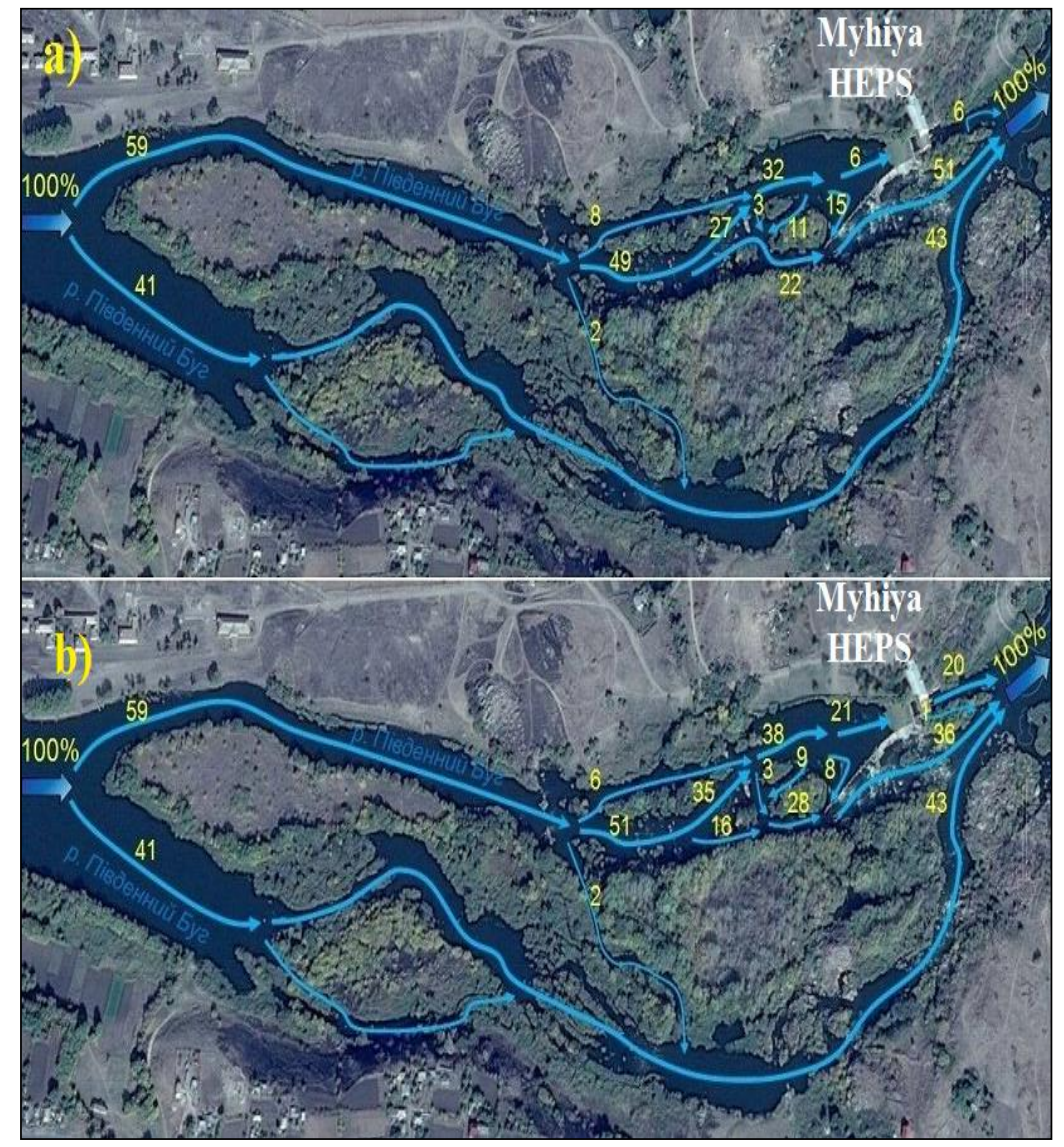

Fig. 8. Changes in the distribution of flow on the water system in the area of the Myhiya hydroelectric power station after its introduction

Flow distribution: $a$ ) - before start of hydraulic turbines (18.07.2017), b) - after start of hydraulic turbines in 2017 (23.07.2018)

Reducing water consumption at rapids also has positive aspects for the aquatic ecosystem of the site. With decreasing water costs, the flow rates of water have decreased, allowing certain flora and fauna species to more effectively stay on rocky thresholds and grow, increasing the biodiversity of the site. 
Similar studies were carried out by us and other lowland rivers, particularly in the lower section of the Dnieper, $5,7,8,9,10,11,12,13,14$. They showed that the mobility of the water mass (water exchange processes) is one of the most environmentally significant factor aqueous medium regardless of the size of the water object.

In the downstream of the hydroelectric station and the discharge channel, due to the flow of large volumes of water, a section with intensive movement of water masses was formed. Due to the

${ }^{5}$ Korzhov Ye.I., Kucheriava A.M. Peculiarities of External Water Exchange Impact on Hydrochemical Regime of the Floodland Water Bodies of the Lower Dnieper Section. Hydrobiological Journal - Begell House (United States). 2018. Vol. 54. Issue 6. P. 104-113.

${ }^{6}$ Timchenko V.M., Korzhov Ye.I., Guliayeva O.A., Batog S.V. Dynamics of Environmentally Significant Elements of Hydrological Regime of the Lower Dnieper Section. Hydrobiological Journal - Begell House (United States). 2015. Vol. 51. Issue 6. P. 75-83.

${ }^{7}$ Тімченко В.М., Гільман В.Л., Коржов С.І. Основні фактори погіршання екологічного стану пониззя Дніпра. Гідрологія, гідрохімія, гідроекологія. 2011. Том 3(24). С. 138-144.

${ }^{8}$ Коржов Є.І. Зовнішній водообмін руслової та озерної систем пониззя Дніпра в сучасний період. Гідрологія, гідрохімія і гідроекологія. 2013. Том 2 (29). C. $37-45$.

${ }^{9}$ Коржов Е.И. Влияние климатических изменений на территории Украины на термический и ледовый режимы устьевого участка Днепра. Bодные pecypcbl, экология и гидрологическая безопасность: сборник трудов VII международной научной конферениии молодых ученых и талантливых студентов ФГБУН ИВПРАН. 2013. 11-13 декабря С. 51-54.

${ }^{10}$ Коржов С.І. Особливості формування донних відкладів водойм пониззя Дніпра 3 різною інтенсивністю зовнішнього водообміну. Наукові читання присвячені 95-річчу НАН Украӥни. 2014. № 6. С. 27-32.

${ }^{11}$ Коржов Є.І., Мінаєва Г.М. Вплив режиму течій на кількісні показники фітопланктону мілководних водойм пониззя Дніпра. Гідрологія, гідрохімія $i$ гідроекологія. 2014. Том 2 (33). С. 61-65.

12 Тимченко В.М., Коржов Е.И., Гуляева О.А., Дараган С.В. Динамика экологически значимых элементов гидрологического режима низовья Днепра. Гидробиологический журнал. 2015. Т. 51, № 4. С. 81-90.

${ }^{13}$ Коржов Є.І., Кучерява А.М. Особливості впливу зовнішнього водообміну на гідрохімічний режим заплавних водойм пониззя Дніпра. Гидробиологический журнал. 2018. Вып. 54, № 4. С. 112-120.

${ }^{14}$ Коржов Є.І. Науково-практичні рекомендації щодо покращення стану водних екосистем гирлової ділянки Дніпра шляхом регулювання їх зовнішнього водообміну. 2018. 52 с. 
considerable flow of water and the relatively small capacity of the channel of the flow velocity in the specified area, they reach values of $1.5-1.8 \mathrm{~m} / \mathrm{s}$. Fast turbulent flow promotes considerable mixing of water masses, both horizontally and vertically. Compared to the field survey data we conducted in 2017 prior to the launch of the hydro turbines, the environmental status of the site has improved in hydrological terms. The congestion area, which covered the area of the entire wastewater channel, disappeared completely after the start of the hydraulic turbines. The small fractional silt and the aquatic vegetation that had accumulated here for many years, under the influence of the erosion ability of the stream, completely disappeared. Depths in the channel have now increased from $0.8-1.0 \mathrm{~m}$ (July 2017) to $1.6-1.8 \mathrm{~m}$. However, it should be noted that the high turbulent activity of the water stream has a significant erosion ability, so at this site it is worth considering the possibility of installing additional coastal fortifications and to conduct regular inspection of the coast here once a year after a steady passage of spring flood (tentatively in June).

The resulting redistribution in the field of velocities and water flow in the area of the hydroelectric power station contributed to the alignment of ecosystem indicators to the average level - the most flowing parts of the water body became less flowing, and in the stagnant zones the flow increased.

A more even distribution of water flow through the water system due to the operation of the Myhiya HEPS reflected in the distribution of sediments and sediments in the area of constant impact. Compared to field surveys in July 2017, the capacity of silt above the hydroelectric power station in the region of the left bank decreased by $0.15-0.20 \mathrm{~m}$, indicating a positive change in the status of the aquatic ecosystem of the site. In the central part of the area above the hydroelectric power station, the silt capacity decreased by $0.05-0.10 \mathrm{~m}$.

In the area of influence below the hydroelectric power station, a complete transformation of the soil complex took place. Due to the stormy stream of water, the bottom is represented by well-washed sand and stones. Only at a distance of $100 \mathrm{~m}$ from the downstream along the coast, mainly in reeds thickets, there is a slight seasonal muddy of the bottom. 
It should be noted that the process of redistribution of the soil complex in the zone of permanent impact is not complete, so we should expect further changes of this element of the aquatic ecosystem. Soil redistribution takes a certain amount of time (2-4 years), and blurred bottom sediments may, during this period, become watersuspended substances that can cause a temporary decrease in the transparency of downstream water, saturation of their organic and biogenic substances. In the feedback and bypass channel, the change of soils, due to the constant dynamic action of the water flow, is almost complete. According to eyewitnesses, during the start of the hydroelectric power station, as previously predicted, there was a shortterm disturbance of the water masses in the downstream Southern Bug River network. During a observations in July 2018, we did not find changes in the transparency of water masses in the canal network under the Myhiya hydroelectric power station.

At the site above the hydroelectric power station as of July 2018, the process of soil reformation has not been completed, so here it is possible to increase the turbidity of water during the passage of spring waterfalls and heavy rain floods. The transportation of suspended substances in the water will also be temporary in nature and, according to our calculations, will occur at a site $1.2 \mathrm{~km}$ below the Myhiya hydroelectric station. At an average velocity in the Southern Bug River channel network below the hydroelectric power station $0.10-0.12 \mathrm{~m} / \mathrm{s}$, the particles washed away by the water flow from the upper stream can be attributed to a distance of 1.1-1.2 km. Under such conditions, the maximum possible zone of temporary (short-term) impact will be $24780 \mathrm{~m}^{2}$ with a channel capacity of about $44600 \mathrm{~m}^{3}$.

In general, the restoration of the Myhiya hydroelectric power station is a factor that has positively influenced the functioning of the aquatic ecosystem of the river within the impact zone, in particular its abiotic components. Water masses in the studied area, compared to the previous inspection (before the introduction of hydroelectric power stations), became more dynamically active, their processes of selfpurification were activated.

Thus, the current operation of the Myhiya hydroelectric power station did not adversely affect the distribution of abiotic and functioning of biotic components of the aquatic ecosystem, the processes of water quality formation and the sanitary and biological state of the Southern Bug River. 


\section{CONCLUSIONS}

The long-term presence of the Southern Bug River aquatic ecosystem in the area of the Myhiya hydroelectric power station influence in a partially without running state caused a number of negative ecological aspects, which for many years had a negative impact on the state of the surrounding aquatic environment.

The resumption of the Myhiya hydroelectric power station in 2017 on the plain of the river significantly improved the abiotic indices of the aquatic ecosystem in the area of Myhiya village. After the hydropower station was launched, a number of elements of the hydrological regime were reformed. An increase in the dynamic activity of the water masses, after the hydropower turbines was restored, had a positive effect on the transformation of bottom sediments in the left-bank and central sections of the water area above the dam and dramatically changed the characteristics of the biotope in the lower stream of the hydroelectric power station. In particular, the capacity of silt bottom sediments in the area of influence of the Myhiya hydroelectric power station decreased by $20-40 \%$, and the congestion zone disappeared completely in the feedback channel.

In general, the restoration of the Myhiya hydroelectric power station is a factor that has positively influenced the functioning of the aquatic ecosystem of the river within the impact zone, in particular its abiotic components. Water masses in the studied area, compared to the previous inspection (before the introduction of hydroelectric power station), became more dynamically active, their processes of selfpurification were activated.

Thus, the operation of small hydropower stations has virtually no adverse effect on the aquatic environment of the plain rivers and is one of the most environmentally friendly types of electricity production.

\section{SUMMARY}

The article examined the ecohydrological aspects of the impact of small hydropower stations without intra-annual regulation on aquatic ecosystems and biotopes, which are located in the zone of their influence on plain rivers.

We chose the zone of the Myhiya hydroelectric power station influence, which is located on the section of the Southern Bug River near the Myhiya village in Ukraine. The reports showed that it was 
possible to fill the tidal base with the water system of the Southern Bug River in the zone of the HEPS influence at the often without flowing station, a number of negative environmental aspects were seen, some of which were negatively visible at the station.

The restoration of the Myhiya hydroelectric power station had a positive effect on the functioning of the river aquatic ecosystem within the impact zone, in particular its abiotic components. Water masses in the studied area, compared with the previous decades, became more dynamically active, their processes of self-purification were activated. From the material considered, it can be concluded that the operation of small hydroelectric power station has virtually no negative impact on the aquatic environment of the plain rivers and is one of the most environmentally friendly types of electricity production.

\section{REFERENCES}

1. Тімченко В.M. Екогідрологія. Досвід досліджень у Дніпровсько-Бузькій гирловій області // Таврійський науковий вісник “Сучасні проблеми аквакультури”. 2003. Вип. 29. C. $187-192$.

2. Тимченко В.М. Экологическая гидрология: предмет, задачи, методы, опыт исследований в Украине. Гидробиологический журнал. 1993. Вып. 29, № 4. С. 3-15.

3. Водне господарство в Україні. За ред. А. В. Яцика, В. М. Хорєва. 2000. 456 с.

4. Фельзенбаум А.И. Теоретические основы и методы расчета установившихся морских течений. 1960. 126 с.

5. Korzhov Ye.I., Kucheriava A.M. Peculiarities of External Water Exchange Impact on Hydrochemical Regime of the Floodland Water Bodies of the Lower Dnieper Section. Hydrobiological Journal - Begell House (United States). 2018. Vol. 54. Issue 6. P. 104-113.

6. Timchenko V.M., Korzhov Ye.I. , Guliayeva O.A., Batog S.V. Dynamics of Environmentally Significant Elements of Hydrological Regime of the Lower Dnieper Section. Hydrobiological Journal Begell House (United States). 2015. Vol. 51. Issue 6. P. 75-83.

7. Тімченко В.М., Гільман В.Л., Коржов С.І. Основні фактори погіршання екологічного стану пониззя Дніпра. Гідрологія, гідрохімія, гідроекологія. 2011. Том 3(24). С. 138-144. 
8. Коржов Є.І. Зовнішній водообмін руслової та озерної систем пониззя Дніпра в сучасний період. Гідрологія, гідрохімія $i$ гідроекологія. 2013. Том 2(29). С. 37-45.

9. Коржов Е.И. Влияние климатических изменений на территории Украины на термический и ледовый режимы устьевого участка Днепра. Водные ресурсы, экология и гидрологическая безопасность: сборник трудов VII международной научной конференции молодых ученых и талантливых студентов ФГБУН ИВПРАН. 2013. 11-13 декабря С. 51-54.

10. Коржов Є.І. Особливості формування донних відкладів водойм пониззя Дніпра 3 різною інтенсивністю зовнішнього водообміну. Наукові читання присвячені 95-річчу НАН України. 2014. Вип. 6. С. 27-32.

11. Коржов Є.I., Мінаєва Г.М. Вплив режиму течій на кількісні показники фітопланктону мілководних водойм пониззя Дніпра. Гідрологія, гідрохімія і гідроекологія. 2014. Том 2(33). C. $61-65$.

12. Тимченко В.М., Коржов Е.И., Гуляева О.А., Дараган С.В. Динамика экологически значимых элементов гидрологического режима низовья Днепра. Гидробиологический журнал. 2015. Вып. 51, № 4. С. 81-90.

13. Коржов Є.I., Кучерява А.М. Особливості впливу зовнішнього водообміну на гідрохімічний режим заплавних водойм пониззя Дніпра. Гидробиологический журнал. 2018. Вып. 54, № 4. С. 112-120.

14. Коржов Є.I. Науково-практичні рекомендації щодо покращення стану водних екосистем гирлової ділянки Дніпра шляхом регулювання їх зовнішнього водообміну. 2018. 52 с.

Information about the author: Korzhov Ye. I., $\mathrm{PhD}$, Candidate of Geographic Sciences, Senior Researcher, Kherson Hydrobiological Station of National Academy of Sciences of Ukraine 87, M. Fortus str., Kherson, 73000, Ukraine 